\title{
PM10 emissions due to storage in coal piles in a mining industrial area
}

\author{
R. Rojano ${ }^{1,2}$, H. Arregocés ${ }^{1,2}$, L. Angulo ${ }^{3}$ \& G. Restrepo ${ }^{2}$ \\ ${ }^{1}$ GISA Research Group, Faculty of Engineering, \\ University of La Guajira, Colombia \\ ${ }^{2}$ Applied Physicochemical Processes Group, Engineering College, \\ Antioquia University, Colombia \\ ${ }^{3}$ GEAB-CIDTEC Research Group, Faculty of Engineering, \\ Cesar University, Colombia
}

\begin{abstract}
Fugitive material has been identified as the main source of air pollution, especially total suspended particulate (TSP) and particulate matter less than 10 micrometers $\left(\mathrm{PM}_{10}\right)$ in open pit mining. The aim of this research was to estimate the concentration of $\mathrm{PM}_{10}$ and measure the impact of coal piles on nearby populations. The sources under consideration are three different areas for coal storing. All three areas are distributed along the mine with 14 piles with a total capacity of 3.2 Mton. Emissions were estimated and the contribution of $\mathrm{PM}_{10}$ for the activities of loading, unloading, hauling coal, tractor operations and wind disturbances on the surface of the coal piles using the emission factors suggested by EPA. The contribution to environmental receptors was determined with the dispersion model CALPUFF. Although higher emissions occur in solar hours, characterised by high values of wind speed and higher insolation, the greater receptivity $\mathrm{PM}_{10}$ measurements stations occur during the night hours by decreasing the mixing height. The model show that the activities involved in coal storage can provide $14.5 \%$ of daily environmental concentrations in receptors located $16.2 \mathrm{~km}$ downwind of the source, which showed that CALPUFF can be used for complex terrain and short distance from the source of emission.

Keywords: CALPUFF, PM 10 , piles, coal, emissions, open pit.
\end{abstract}




\section{Introduction}

Colombia is the largest producer of coal in Latin America and the twelfth in the world. Its total reserves are estimated at around 17,000 Mtons, of which 6508 Mtons have been measured. Of this measured total 3694.61 Mtons are located in the department of La Guajira, located in northern Colombia (Murie et al. [1]). South of this department is located the Cerrejón mine. The reserves in the Cerrejón have been measured in 3694.91 Mtons, corresponding to $56.77 \%$ of the total reserves of the country [2,3]. Over six years (2009-2014) Cerrejón has maintained coal production over 30 Mtons, projected to increase production to 40 Tons by 2016 (ANLA [4]). The environmental impacts of an open pit coal mine are related to six areas of interest: air quality, water quality and quantity, acid mine drainage, land impacts, ecological impacts and economic impacts (Jain et al. [5]). The open pit coal mine generates greater environmental impacts than underground mining, mainly on air quality due to particulate and gaseous pollutants emitted into the atmosphere [6-8]. The sources of air pollution in areas of coal mining generally include activities such as drilling, blasting, loading and unloading of overburden, loading and unloading of coal, traffic on unpaved surfaces, coal storage piles (wind erosion and maintenance) and maintenance of roads [9-11]. The fugitive material has been identified as the main source of air pollution, especially total suspended particulate (TSP) and particulate matter less than 10 micrometers $\left(\mathrm{PM}_{10}\right)[12,13]$. Amponsah-Dacosta [9] in a study on mine South Africa reported that the main sources of emission in importance of $\mathrm{PM}_{10}$ in open pit coal mine are traffic on unpaved surfaces (78.4\%), topsoil $(7.5 \%)$, loading and unloading of overburden $(4.6 \%)$, coal removal $(2.3 \%)$, wind erosion (stockpiles and exposed areas) $(2.3 \%)$ However, the emission rates in the Cerrejón mine are different compared to South African mines due to differences in the nature of mining, geological conditions, control measures, extraction process and climatic conditions. $68.5 \%$ of the total emission of $\mathrm{PM}_{10}$ in the Cerrejón mine is due to traffic on unpaved surfaces and in fourth place coal storage piles (wind erosion and maintenance) with $0.1 \%$, which is the activity of interest of this study (Rojano et al. [14]).

In surface coal mining it is common practice to store coal in large piles. The piles, usually worked by bulldozers, are subject to wind erosion causing emission of $\mathrm{PM}_{10}$ and TSP. $\mathrm{PM}_{10}$ particles are associated with impacts to public health. Research has shown coincidences between persons living near coal mining sites and elevated population mortality rates $[15,16]$. A recent study showed evidence for biological impact among people living in mining communities (Hendryx and Entwhistle [17]). Other researchers showed evidence in relationships between all cancer mortality and lung cancer incidence and mortality with proximity to a coalmine. However, the researchers suggested more studies where the environmental effects of coal mining should be explored using individual-level exposures and cancer outcomes (Mueller et al. [18]).

$\mathrm{PM}_{10}$ emissions by wind erosion were calculated using emission factors (USEPA [19]). Cerrejón is using as a tool for modeling and planning the AERMOD dispersion model (Cerrejón [20]). This modeling tool is generally 
recommended for influence areas under 50 kilometers $(<50 \mathrm{~km})$ nevertheless; AERMOD does not consider the temporal and spatial variations in the transport direction of the plume. Although CALPUFF is generally recommended for long range dispersion calculations $(>50 \mathrm{~km})$, can be used on a case-by-case basis also for near field applications [21, 22]. This model has been used in many investigations in complex terrain and was used in this type of source [21, 23, 24]. In this research, the CALPUFF model was used to estimate the concentrations of $\mathrm{PM}_{10}$ in the receptors on human settlement, whit meteorological data of stations located and operated by the Cerrejón. The objective of this research was to estimate the concentration of $\mathrm{PM}_{10}$ and measure the impact of coal piles on nearby populations.

\section{Methods}

\subsection{Study area}

The open pit coal mining operation, Cerrejón, is located in northern Colombia in the La Guajira Department, east of the Sierra Nevada de Santa Marta and west of the Perijá Mountains, in line with the Venezuela's border. It is located $11^{\circ} 5^{\prime} 2^{\prime \prime}$ north and $72^{\circ} 40^{\prime} 31^{\prime \prime}$ west (fig. 1).

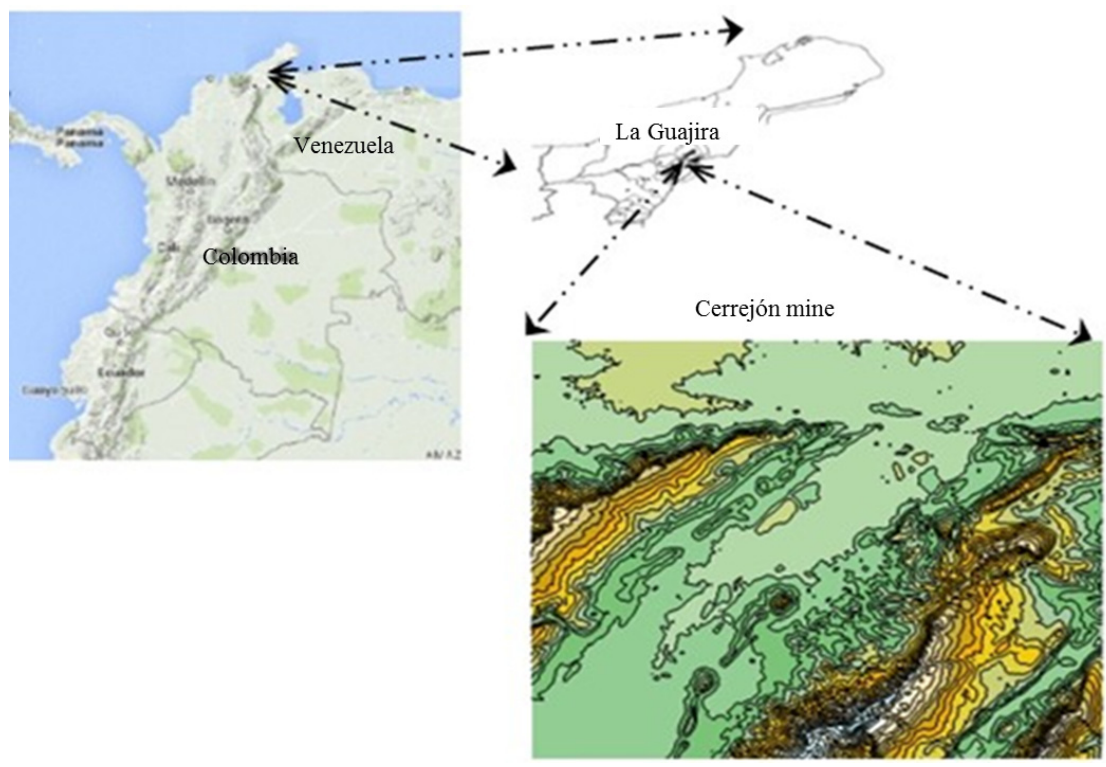

Figure 1: Geographic localization of the Cerrejón coal mine in La Guajira (Caribbean region of Colombia).

Cerrejón coal mining is administratively distributed in the Cerrejón northern zone (CNZ), Cerrejón central zone (CCZ), and Cerrejón southern zone (CSZ). 
The mining operation reached a coal production of 33.4 Mtons during 2015, with approved expansion plans to increase production to $42 \mathrm{Mt}$ in 2016 (Cerrejón [25]). The mine has three areas for storing coal, whit 18 piles daily maintenance. All piles store up to 3.2 Tons of coal. The coal mine borders three municipalities with a population of 59.089 inhabitants of which $34 \%$ are indigenous. Of this population, approximately $70 \%$ (41,362 inhabitants) living areas of influence of the mine $(<10 \mathrm{~km})$.

\subsection{Meteorological data}

Due to the region's topographical features, the meteorology information was characterized by data collected from several meteorological stations. The meteorological data used in the analysis were obtained from the Air Quality Network Cerrejón. This network consists of 19 surface stations of which 3 have automatic meteorological sensors. A station upwind the piles of studies (Vivienda) and two stations downwind of piles (Provincial and Casitas). The table 1 describe the location of the 4 monitoring stations of meteorological date for the year 2014 their location and elevations. Information vertical sounding was obtained from the Almirante Padilla Station (Lat $-72^{\circ} 93^{\prime}$; long $11^{\circ} 53^{\prime}$, 4 meters elevation) from Riohacha City, 100 kilometers north of the mine.

Table 1: Meteorological information used in the analysis.

\begin{tabular}{|l|c|c|c|c|}
\hline \multicolumn{1}{|c|}{ Stations } & ID & Latitude $\left(^{\circ}\right)$ & Longitude $\left(^{\circ}\right)$ & Elevation $(\mathrm{m})$ \\
\hline Provincial & Pro & 11.022 & -72.742 & 156 \\
\hline Casitas & Cas & 10.955 & -72.741 & 162 \\
\hline Vivienda & CDA & 11.138 & -72.619 & 112 \\
\hline
\end{tabular}

The openair software was used for the review and evaluation of meteorological data. The openair software is freely available as an R package. This package was developed mainly for the analysis of atmospheric science measurement specifically for air pollution.

\subsection{Emission data}

The sources under consideration are three areas for storing coal (A1 to A3) (as shown in fig. 2). 11 piles in the main area were studied for storing coal (A1), 2 auxiliary piles in the southern area of the mine (A3) and 1 pile in the northern of the mine (A2).

For estimating the emission rates of processes, the present study concerning coal storage piles, was used as established by USEPA [26, 27]. The particles emission rate from coal storage piles depends on the wind velocity (friction velocity) and the size of the particles. 


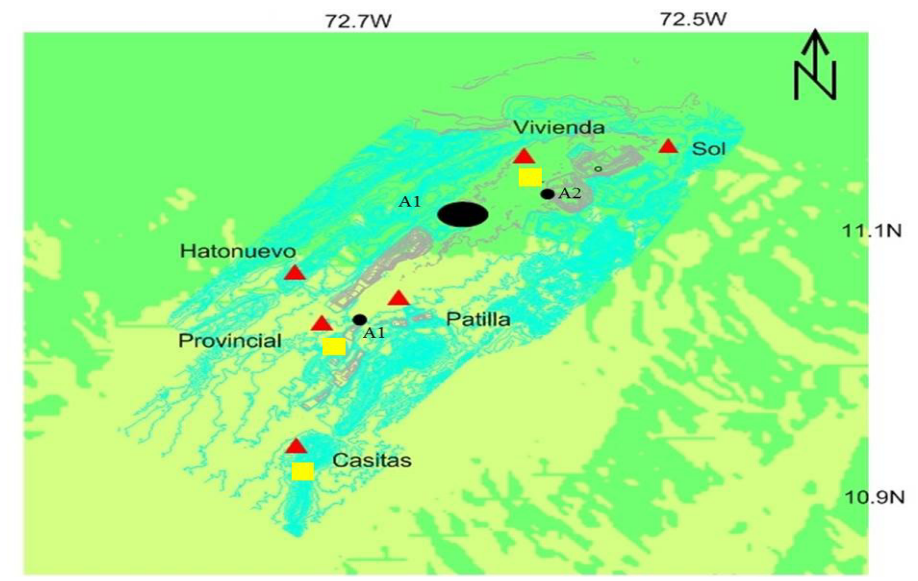

Figure 2: Cerrejón coal mine study area: area piles (black ovals), air quality stations and receptors (red triangles), meteorological stations (yellow rectangles).

The emission factor for wind-generated particulate emissions may be expressed in units of grams per square meter $\left(\mathrm{g} / \mathrm{m}^{2}\right)$ per year as follows:

$$
\text { Factor Emission }=\mathrm{k} \sum_{\mathrm{i}=1}^{\mathrm{N}} \mathrm{P}_{\mathrm{i}}
$$

where $k$ depends on the aerodynamic diameter of the particles, $N$ number of disturbances per year and $P_{i}$ erosion potential. The erosion potential function for a dry as follows:

$$
P_{i}=58\left(\mu^{*}-\mu_{\mathrm{t}}^{*}\right)^{2}+25\left(\mu^{*}-\mu_{\mathrm{t}}^{*}\right)^{2}
$$

where $\mu^{*}$ is friction velocity in the coal storage piles $\mu_{t}^{*}$ is threshold friction velocity $\left(P_{i}=0\right.$ for $\left.\mu^{*} \leq \mu_{t}^{*}\right)$. Because of the nonlinear form of the erosion potential function, each erosion event must be treated separately.

Emissions of $\mathrm{PM}_{10}$ generated by each event are calculated as the product of $k$ $\left(\mathrm{PM}_{10}=0.5\right)$, erosion potential $\left(P_{i}\right)$ expressed in $\mathrm{g} / \mathrm{m}^{2}$, and the area affected by pile.

\subsection{Air quality model}

To determine the contribution on 5 receptors located in villages near the mine, CALPUFF was used (Scire et al. [28]). The model domain covers a grid of $55 \mathrm{~km} \times 45 \mathrm{~km}$ with resolution of cells of $0.25^{2} \mathrm{~km}$. Consisting of 220 grid cells along the $\mathrm{x}$-axis and 180 grid cells along the $\mathrm{y}$-axis. Domain coordinates are between $10^{\circ} 25^{\prime}$ to $11^{\circ} 11^{\prime}$ north latitude and $-73^{\circ} 18^{\prime}$ to $-72^{\circ} 30^{\prime}$ west longitude, which includes all the area of influence of mining activities (as shown in fig. 1). 10 levels of vertical heights $(20,50,80,100,500,1000,1500,2000,3000$ and 
$5000 \mathrm{~m}$ ). The numerical simulation is based on the emission and meteorological dataset for the year 2014. The topography input for CALPUFF was processed in two formats DEM (Digital Elevations Model) generated by the USGS (United States Geological Survey).

\section{Results and discussion}

\subsection{Meteorology}

In this study the hourly values of the components were separately summed to obtain daily data. The monthly average and the standard deviation of meteorological parameters are listed in Table 2 for each station. Wind roses are a common way to present information on the distribution of wind speed and directions (Hopke [29]). As observed in the three stations, the wind speed is $3.08 \mathrm{~m} / \mathrm{s}$ for Provincial, $3.09 \mathrm{~m} / \mathrm{s}$ for Casitas and $2.43 \mathrm{~m} / \mathrm{s}$ for Vivienda, with low speeds and very low percentage of calm wind hours $(0.05 \%)$. The temperature varies from 24.61 to $29.67^{\circ} \mathrm{C}$. Low precipitation occurs due to the presence of El Niño phenomenon. Figure 3 shows that the main winds in the Cerrejón mine are from the NE. Wind patterns indicates that $\mathrm{PM}_{10}$ emissions from piles significantly affect stations of Provincial, Hatonuevo and Patilla.

Table 2: Daily averages of meteorological parameters in the period JanuaryDecember 2014.

\begin{tabular}{|l|c|c|c|}
\hline \multirow{2}{*}{ Parameter } & \multicolumn{3}{|c|}{ Mean (standard deviation) } \\
\cline { 2 - 4 } & Provincial & Casitas & Vivienda \\
\hline Temperature $\left({ }^{\circ} \mathrm{C}\right)$ & $24.6(2.2)$ & $29.7(2.08)$ & $28.6(2.2)$ \\
\hline Wind $(\mathrm{m} / \mathrm{s})$ & $3.1(1.1)$ & $3.09(1.06)$ & $2.4(0.8)$ \\
\hline RH $(\%)$ & $68.3(8.1)$ & $69.4(9.80)$ & $70.3(7.8)$ \\
\hline Barometric Pressure $(\mathrm{mmHg})$ & $756(1.0)$ & $757(0.95)$ & $758(1.0)$ \\
\hline Precipitation $\left(\mathrm{mm} \mathrm{H}_{2} \mathrm{O}\right)$ & $1.7(0.3)$ & $1.6(0.85)$ & $1.5(0.30)$ \\
\hline
\end{tabular}

The central area for storing coal affects directly the Provincial and Hatonuevo stations where there are small communities of indigenous Wayuu native to the region.

\subsection{Emission}

The emission of $\mathrm{PM}_{10}$ by erosion and activity in piles was estimated using emissions factors recommended by the USEPA. The results showed that are emitted $4.71 \mathrm{E}-05 \mathrm{~g} / \mathrm{m}^{2} \mathrm{~s}$. Of these, the $27 \%$ is due to emissions generated by wind and $77.68 \%$ is due to maintenance for bulldozers, the loading and unloading of coal and vehicle traffic around the piles (Table 3 ). 

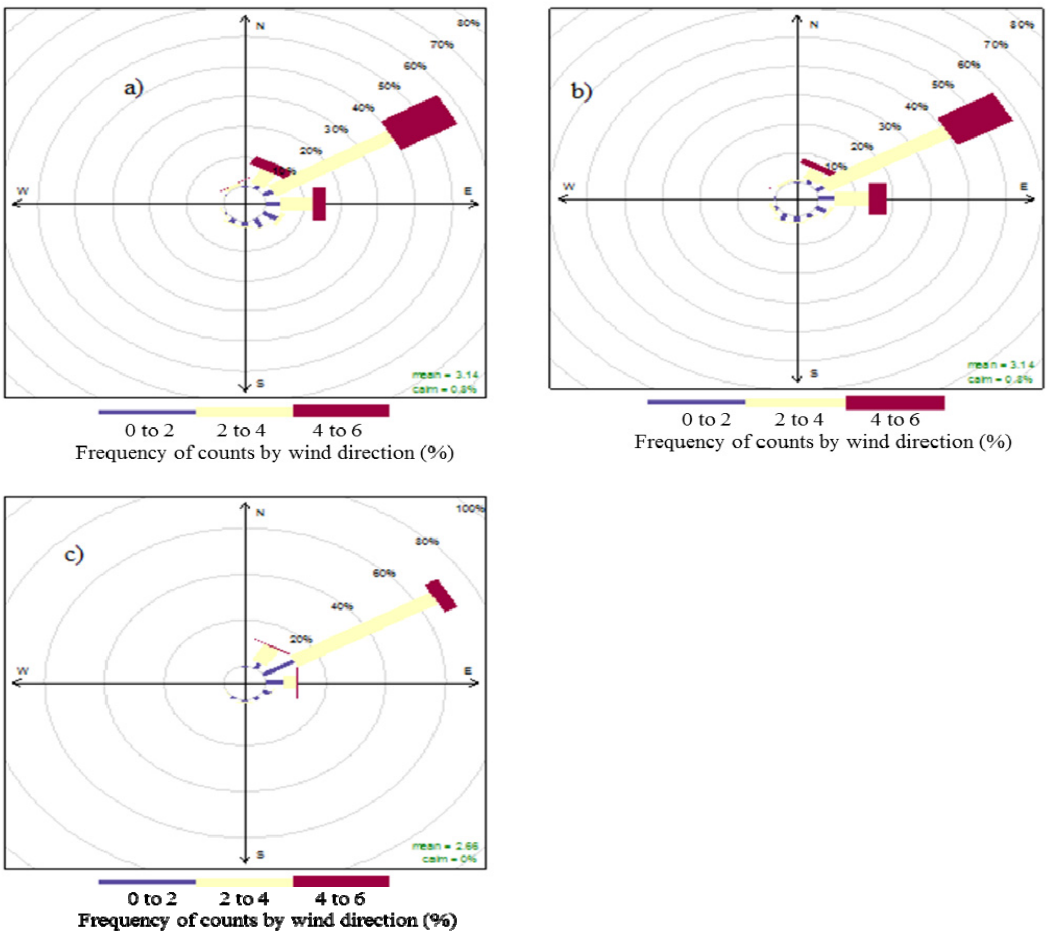

Figure 3: Wind roses based on meteorological data of Cerrejón mine. (a) Provincial station; (b) Casitas station and (c) Vivienda station from 2014 period.

Table 3: $\quad \mathrm{PM}_{10}$ emission by erosion and activity in piles.

\begin{tabular}{|l|l|l|l|}
\hline Source & Operation & Specific activity & Emission \\
\hline \multirow{4}{*}{ Active storage pile } & \multirow{3}{*}{ Maintenance } & Bulldozers & $6.78 \mathrm{E}-06$ \\
\cline { 3 - 4 } & & Truck loading & $4.11 \mathrm{E}-06$ \\
\cline { 3 - 4 } & & Truck unloading & $4.11 \mathrm{E}-06$ \\
\cline { 3 - 4 } & & Vehicle traffic in piles & $1.60 \mathrm{E}-05$ \\
\cline { 3 - 4 } & Wind erosion & & $1.14 \mathrm{E}-05$ \\
\hline
\end{tabular}

Similar results to the presented by Cerrejón [20], in planning daily activities. The greatest contribution is provided by vehicle traffic around the piles. This is an important activity in the mine because allows load coal for final disposal. This mining activity always is made and providing particulate matter $\mathrm{PM}_{10}$ to receptors. 


\subsection{Contribution of $\mathrm{PM}_{10}$}

The daily contributions of $\mathrm{PM}_{10}$ were significant and variables for each of the stations (Figure 4). The modeling showed that $13.8 \%$ of the environmental concentration recorded in Provincial station is directly influenced by activities related to the storage of coal, while, in other areas studied the influence was lower: Casitas: 3.43\%, Patilla: 3.08\% and Hatonuevo: 2.24\%. Was not presented contribution by the activities of storage in piles of coal in the station Vivienda, indicating that in the period of study was not recorded inversion of wind. The factor wind direction, was determinant for the contribution in receptors, its frequency during the time of it modeling was NEE.

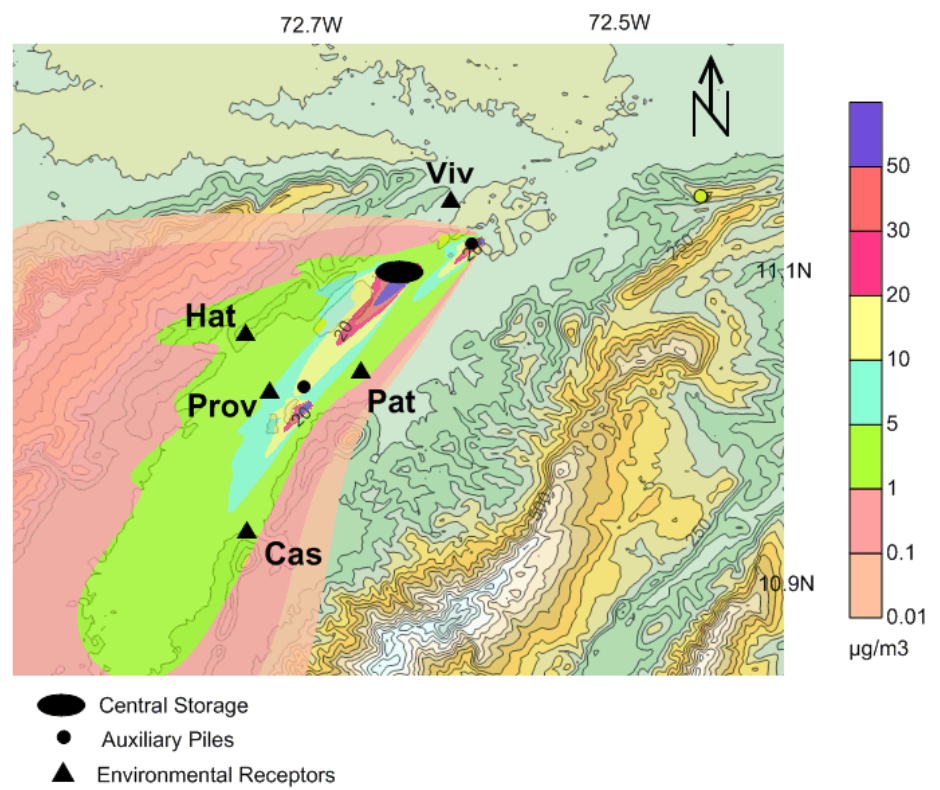

Figure 4: Atmospheric dispersion of $\mathrm{PM}_{10}$ in the mining area emitted by coal storage.

Rojano et al. [30] determined average concentrations in the Provincial station of $32.90 \mu \mathrm{g} / \mathrm{m}^{3}$ in the same area of study. Estimating the contribution in mass using this information, can be recording a concentration of $5.5 \mu \mathrm{g} / \mathrm{m}^{3}$. The model estimated a contribution, which indicates $3 \mu \mathrm{g} / \mathrm{m}^{3}$. This indicates an approximation of $55 \%$ to the study cited.

Fig. 4 shows the $\mathrm{PM}_{10}$ results obtained by CALPUFF using the three stations meteorology for 2014 indicates that the air quality model identifies areas near to the three areas for storing coal (A1 to A3 of Figure 1) does not exceed the national annual standard in the receptors. The model suggests that can be achieved the $50 \mu \mathrm{g} / \mathrm{m}^{3}$ in the site close to the piles. In other words, regardless of 
the model and the meteorology used, the results showed that the areas with the highest concentrations correspond to the location of the emission sources. $\mathrm{PM}_{10}$ concentrations decreased with increasing distance from the emission source. This observation is consistent with the experimental results reported by Huertas et al. [31] in studies in mines more to the south of Cerrejón. Is important to emphasize that although not reached levels that exceed the standard, the contribution of this source is signified to environmental impact in the area.

\section{Conclusions}

In this study CALPUFF was found to predict concentrations of particulate matter $\mathrm{PM}_{10}$. The model was used to quantify the average contribution of $\mathrm{PM}_{10}$ in 13 piles in the main area for storing coal. Concentrations were estimates using meteorological observations from stations located in the coal mining Cerrejón. Maximum concentrations are reached close to the emission source. Although concentrations do not exceed the national standards, the contribution of this source is signified to environmental impact in the area. The contribution to concentrations of $\mathrm{PM}_{10}$ in areas with the presence of communities can reach $14.5 \%$.

\section{Acknowledgement}

This project was financed by Colciencias-Cerrejón, code 1115-524-30465, the Sustainability Strategy 2013-2014 of Program at the University of Antioquia (Colombia) and the University of La Guajira.

\section{References}

[1] Muriel, A., Gamba, G., Fierro L. \& Mejía, S.A, Plan Nacional para el Desarrollo Minero: visión al año 2019, Preprensa: Bogota D.C., pp. 2045, 2006.

[2] Monroy, Á.C., Castillo, S.C., Niño, L.C., Ríos, L.M., Aramburo, S.A., Quintero, R.S., Morales, Y.O., Alvarez, G.P., Isaza C.A., Baena, O.J., Gaviria, J.A., García, S.B., Londoño, P.E., Rodas, J.F., Perea C.G. \& Larsen U.L, Simulación y evaluación del impacto de estrategias en el desarrollo del sector minero 2014-2032, Universidad Nacional De Colombia: Bogota D.C. pp. 120-190, 2014.

[3] Candil, N.A., Moreno, J.R., Castañeda, J.F., Villazón, R.A. \&. Galvis, J.J., La Cadena del Carbón, Imprenta Nacional de Colombia: Bogota D.C., pp. 11-45, 2012.

[4] ANLA, Por el cual se modifica un Plan de Manejo Ambiental-Cerrejón. Colombia, ANLA - Autoridad Nacional de Licencias Ambientales, Bogota D.C., pp. 120-168, 2014.

[5] Jain, R., Cui, Z. \& Domen J.K., Environmental Impacts of Mining, (Chapter 4). Environmental Impact of Mining and Mineral Processing, ed. Boston: Butterworth-Heinemann: Boston, pp. 53-157, 2016. 
[6] Ghose, M.K. \& Majee, S.R., Characteristics of hazardous airborne dust around an Indian surface coal mining area, Environmental Monitoring and Assessment, 130(1-3), pp. 17-25, 2007.

[7] Vijay, R. \& Singh, K., Spontaneous heating and fire in coal mines, Procedia Engineering, 62, pp. 78-90, 2013.

[8] Melody, S.M. \& Johnston F.H., Coal mine fires and human health: What do we know?, Int. J. Coal Geol., 152, pp. 1-14, 2015.

[9] Amponsah-Dacosta, F., Cost effective strategies for dust control in an opencast coal mine, University of Witwatersrand: Johannesburg, South Africa, pp. 1-131, 1997.

[10] CMRI, Annual environmental monitoring report for Lakhanpur Area, Dhanbad,www.indiaenvironmentportal.org.in/category/3921/thesaurus/cen tral-mining-research-institute-cmri/

[11] USEPA, Compilation of Air Pollutant Emission Factors. Volume I: Stationary Point and Area Sources. AP 42, Fifth Edition Compilation of Air Pollutant Emission Factors, Volume I Chapter 11: Mineral Products Industry: Western Surface Coal Mining, Western Surface Coal Mining, 1995. Online: www3.epa.gov/ttn/chief/ap42/ch11/final/c11s09.pdf.

[12] Cowherd, C., Muleski, G.E. \& Kinsey, J.S., Control of open fugitive dust sources, United States Environmental Protection Agency (USEPA): Kansas, 1988.

[13] Ghose M.K. \& Majee S.R., Assessment of dust generation due to opencast coal mining an Indian case study, Environmental Monitoring and Assessment, 61, pp. 255-263, 2000.

[14] Rojano, R., Arregoces, H. \& Restrepo G., Eficiencia en la reducción de emisiones de $\mathrm{PM}_{10}$ en un pit de una mina de carbón a cielo abierto, Proc. VIII Congreso Latinoamericano de Ciencias Ambientales, ed. R. Toro, Sociedad de Quimica Ambiental de Chile, Pucon, pp. 44-45, 2015.

[15] Hendryx, M., The public health impacts of surface coal mining, The Extractive Industries and Society, 2(4), pp. 820-826, 2015.

[16] Hendryx, M. \& Zullig K.J., Higher coronary heart disease and heart attack morbidity in Appalachian coal mining regions, Preventive Medicine, 49(5), pp. 355-359, 2009.

[17] Hendryx, M. \& Entwhistle, J., Association between residences near surface coal mining and blood inflammation, The Extractive Industries and Society, 2(2), pp. 246-251, 2015.

[18] Mueller, G.S., Clayton, A.L., Zahnd, W.E., Hollenbeck, K.M., Barrow, M.E., Jenkins, W.D. \& Ruez, Manuscript title: Geospatial analysis of cancer risk and residential proximity to coal mines in Illinois, Ecotoxicology and Environmental Safety, 120, pp. 155-162, 2015.

[19] USEPA, Compilation of Air Pollutant Emission Factors. Volume I: Stationary Point and Area Sources. AP 42, Fifth Edition Compilation of Air Pollutant Emission Factors, Volume I, Chapter 13: Miscellaneous Sources, Industrial Wind Erosion, Online. www3.epa.gov/ttn/chief/ ap42/ch13/index.html 
[20] Cerrejón, Modelación de Calidad del Aire Plan Minero 2013. Carbones del Cerrejón Limited, Albania, pp. 30-35, 2013.

[21] MacIntosh, D.L., Stewart, J.H., Myatt, T.A., Sabato, J.E., Flowers, G.C., Brown, K.W., Hlinka, D.J., \& Sullivan, D.A., Use of CALPUFF for exposure assessment in a near-field, complex terrain setting, Atmospheric Environment., 44(2), pp. 262-270, 2010.

[22] USEPA, Revision to the guideline on air quality models: Adoption of a preferred general purpose (flat and complex terrain), Federal Register 70(216), pp. 68218-68261, 2005.

[23] Tartakovsky, D. Stern, E. \& Broday, D.M., Dispersion of TSP and PM10 emissions from quarries in complex terrain, Science of The Total Environment, 542, pp. 946-954, 2016.

[24] Diego, I., Pelegry, A., Torno, S., Toraño, J. \& Menendez, M., Simultaneous CFD evaluation of wind flow and dust emission in open storage piles, Applied Mathematical Modelling, 33(7), pp. 3197-3207, 2009

[25] Cerrejón, Resumen del Proyecto de Expansión Iiwo'uyaa para Grupos de Interes, Cerrejón Limited, Bogota D.C., 2011.

[26] USEPA, Source assessment coal storage piles, US Environmental Protection Agency: Cincinnaty, pp. 65-99, 1978.

[27] USEPA, Compilation of Air Pollutant Emission Factors. Volume I: Stationary Point and Area Sources. AP 42, Fifth Edition Compilation of Air Pollutant Emission Factors, Volume I, Chapter 13: Aggregate Handling and Storage Piles, Online. www.epa.gov/ttn/chief/ap42/ index.html.

[28] Scire, J.S., Strimaitis, D.G. \& Yamartino, R.J., A User's Guide for the CALPUFF Dispersion Model, Eearth Tech. Inc: Concord, MA, pp. 125$521,2000$.

[29] Hopke, P.K., Utilizing Meteorological data to identify local sourcestle, Center for Air Resources Engineering and Science: Potsdam, NY pp. 113, 2014.

[30] Rojano, R., Angulo, L., \& Restrepo G., Concentración y relación de PST, $\mathrm{PM}_{10}$ y PM2.5 en poblaciones cercanas a minería a cielo abierto: caso Cerrejón Colombia, Rev. la Fac. Ing. U.C.V, 30(1), pp. 1-10, 2015.

[31] Huertas, J.I., Huertas, M.E., Izquierdo, S. \& Gonzalez, E.D., Air quality impact assessment of multiple open pit coal mines in northern Colombia, Journal of Environmental Management., 93(1), pp. 121-129, 2012. 